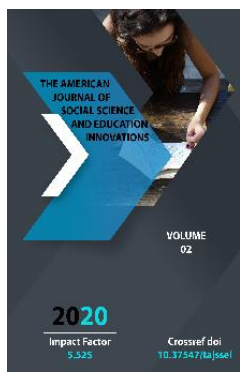

\title{
Studying Stone Paintings: Tepakiyasoy Petroglifs
}

\author{
Oynazarov Holiyor Goyibnazarovich \\ Lecturer Of The Department Of History Of Uzbekistan And Source Studies, Termez State \\ University, Uzbekistan
}

Copyright: Original content from this work may be used under the terms of the creative commons attributes 4.0 licence.

\section{ABSTRACT}

By studying the Tepakiyasay petroglyphs, it is possible to enrich the scientific understanding and conclusions about the emergence and development of the first works of art in the territory of Uzbekistan. These stone paintings serve as an important source for studying the mythological and religious worldviews and imaginations of the ancient people who lived there.

\section{KEYWORDS}

Zarautsoy, Zarabag, Gadoytopmassoy, Shalkansoy, O’zbeksoy, Karabaksoy, rock paintings, Burguttepa, Kayritsoy

\section{INTRODUCTION}

The role and importance of material, cultural and archeological heritage monuments in the large-scale and comprehensive study of the history of our country is incomparable. Such cultural monuments are rock paintings. To date, the location of more than three hundred rock paintings in the Central Asian region has been identified and taken into account (Eshkurbanov, 2014. 103 p.). So far, more than 180 ancient rock paintings have been found in Uzbekistan (Khujanazarov, 2018, p. 18). These cultural monuments are made by carving, sinking, drawing using stone, brass, iron, steel or other hard objects. Paintings made in this style are called petroglyphs in archeology (Kholmatov, 2016. pp. 74-75). The oldest petroglyphs in Uzbekistan belong to the Mesolithic period and are Zarautsoy rock paintings in Kohitangtog (Formozov, 1951. p. 213; Formozov, 1969. p. 103). Painted paintings in the mountains of the Nurata ridge Sangijumansay, Oqsoqolotasay (Kondrikova, 
Khojanazarov, 1992. 21 p.), And A. Occurs in Beklarsay and Almalysay monuments identified by Kholmatov.

\section{MATERIALS AND METHODS}

In 2015, another important innovation was made in the study of the history of primitive art in Surkhandarya. Sh.B. Shaydullaev and L. An Uzbek-Czech international archeological expedition led by Stancho has discovered new rock paintings near the village of Zarabog, 15 $\mathrm{km}$ from the mountainous Zarautsoy in the Sherabad district (Augustinová, Stančo, 2016. p. 122).

The monument to the new rock paintings is located $500 \mathrm{~m}$ south-east of the village of Zarabog in the Sherabad district of
Surkhandarya region, at an altitude of $985 \mathrm{~m}$ above sea level (Augustinová, Stančo, 2016. p. 123). As a result of our research, a set of paintings depicting 42 images on 16 stones from Tepaqiyasay was identified. Their coordinates, altitude and surface area were determined. As a result of our research, Gadoytopmassoy, Kayritsoy, Kampirtepasay, Karabogsay, Shalkansay and Uzbeksay were studied near Zarabog village. The smallest of these streams is Tepaqiyasay. Due to the high end of the Tepaqiyasay, the locals called the river Tepaqiyasay. Tepaqiyasay is located closer to Gadoytopmassoy. We have given a conditional name to the table of stone paintings found in the hill. This conditional name was Zarabog Tepaqiyasay petroglyphs ZTP.

\section{(Table 1)}

\section{Coordinates of the location of rock paintings}

\begin{tabular}{|c|c|c|c|c|c|}
\hline $\mathrm{T} / \mathrm{p}$ & Conditional name & North & South & Sea level (m) & QR code \\
\hline \multicolumn{6}{|c|}{ Tepaqiyasay } \\
\hline 1 & ZTP1 & 37.45 .646 & $\begin{array}{c}066 \\
45.932\end{array}$ & 970 & \\
\hline 2 & ZTP 2 & 37.45 .286 & $\begin{array}{c}066 \\
47.561\end{array}$ & 875 & \\
\hline 3 & ZTP 3 & $37.45 \cdot 272$ & $\begin{array}{c}066 \\
47.580\end{array}$ & 912 & \\
\hline 4 & ZTP 4 & 37.45 .283 & $\begin{array}{c}066 \\
47.178\end{array}$ & 900 & \\
\hline
\end{tabular}


The American Journal of Social Science and Education Innovations (ISSN - 2689-100x)

Published: October 29, 2020 | Pages: 217-222

\begin{tabular}{|c|c|c|c|c|}
\hline 5 & ZTP 5 & 3745.283 & $\begin{array}{c}066 \\
47.178\end{array}$ & 900 \\
\hline 6 & ZTP 6 & 37.45 .275 & $\begin{array}{c}066 \\
47.813\end{array}$ & 904 \\
\hline 7 & ZTP 7 & 3745.270 & $\begin{array}{c}066 \\
47.843\end{array}$ & 902 \\
\hline 8 & ZTP 8 & 3745.269 & $\begin{array}{c}066 \\
47.842\end{array}$ & 902 \\
\hline 9 & ZTP 9 & 3745.282 & $\begin{array}{c}066 \\
47.792\end{array}$ & 901 \\
\hline 10 & ZTP 10 & 37.45 .281 & $\begin{array}{c}066 \\
47.791\end{array}$ & 900 \\
\hline 11 & ZTP 11 & 37.45 .218 & $\begin{array}{c}066 \\
47.569\end{array}$ & 896 \\
\hline 12 & ZTP 12 & 3745.218 & $\begin{array}{c}066 \\
47.569\end{array}$ & 896 \\
\hline 13 & ZTP 13 & 37.45 .285 & $\begin{array}{c}066 \\
47.780\end{array}$ & 900 \\
\hline 14 & ZTP 14 & 3745.272 & $\begin{array}{c}066 \\
47.580\end{array}$ & 912 \\
\hline 15 & ZTP 15 & 3745.640 & $\begin{array}{c}066 \\
47.558\end{array}$ & 870 \\
\hline 16 & ZTP 16 & 3745.640 & $\begin{array}{c}066 \\
47.558\end{array}$ & 870 \\
\hline
\end{tabular}


1. ZTP1 - Located southeast of Soy Zarabog village. At the beginning of the stream, on the right side of the stream, there is a rock $10 \mathrm{~m}$ above the rock. The average size of the stone reflected 3 camels, and 6 mountain goats on the rock.

2. ZTP2 The size of the stone is $2 \mathrm{~m}$ from the average ZTP1 stone. The stone is located 12 $\mathrm{m}$ above the river. The stone depicts 4 mountain goats.

3. ZTP3 The size of the stone is $3-4 \mathrm{~m}$ away from the average ZTP2 stone. The stone is located $10 \mathrm{~m}$ above the river. The stone depicts 3 mountain goats.

4. ZTP4 - The size of the stone is $5 \mathrm{~m}$ from the average ZTP3 stone. The stone is located 15 $\mathrm{m}$ above the river. The stone depicts a man, a horse and a mountain goat.

5. ZTP5 The stone is located in front of the small ZTP4 stone. The stone is located $15 \mathrm{~m}$ above the river. The stone depicts 1 mountain goat.

6. ZTP6 The stone size is $4 \mathrm{~m}$ from the average ZTP5 stone. The rock is located 6 $\mathrm{m}$ above the river. The stone depicts an incomprehensible symbol.

7. ZTP7 The size of the stone is $5-6 \mathrm{~m}$ away from the average ZTP6 stone. The stone is located $7 \mathrm{~m}$ above the river. The stone depicts an incomprehensible symbol.

8. ZTP8 The stone is located in front of a large stone ZTP7. The stone is located $7 \mathrm{~m}$ above the river. The stone depicts an incomprehensible symbol.

9. ZTP9 The stone size is $5 \mathrm{~m}$ lower than the average ZTP8 stone. The stone is located 3 $\mathrm{m}$ above the river. The stone depicts an incomprehensible symbol.

10. ZTP10 The size of the rock is $1 \mathrm{~m}$ higher than the stream inside the average rock stream. The stone depicts 1 mountain goat, 1 circle (cart) and an incomprehensible symbol (possibly a human face).

11. ZTP11 The stone is located inside a large rock stream. The stone is located $2 \mathrm{~m}$ from the stream. There was an incomprehensible sign on the stone.
12. ZTP12 The stone is located inside a large rock stream. The stone depicts 1 circle and 1 mountain goat.

13. ZTP13 The stone is located at a height of 15 $\mathrm{m}$ from the small rock stream. The stone depicts 1 mountain goat.

14. ZTP14 The rock is located at a height of 25 $\mathrm{m}$ from a large rock stream. The stone depicts 4 mountain goats and obscure characters.

15. ZTP15 The stone is located on a large rock at a height of $6 \mathrm{~m}$ from the rock stream. The stone depicts an incomprehensible symbol.

16. ZTP16 The stone is located $6 \mathrm{~m}$ above the large rock stream. The back of the ZTP15 stone has an obscure mark on the stone, a picture of 2 circles (carts) and 2 camels.

\section{RESULTS AND DISCUSSIONS}

The Tepaqiyasay rocks, like the rocks of the surrounding streams, are composed of granite, limestone and fine-grained sandstones. On the flat surfaces of these stones, many paintings were made by ancient artists, mainly on the basis of the techniques of hammering, carving, rubbing and cutting with stone and metal tools. Sarmishsoy (Kabirov, 1976. 33 p.), Ilonlisoy (Shatskiy, 1973. 69 p.),

Qoraqiyasoy (Khojanazarov, 1995. 13 p.), Kudukchasoy (Kholmatov, Khojanazarov, 2014. 103 p.), Noqisoy (Kholmatov, 2010. 166 p.), Soysabak (B. Bobomullaev, 2011.143.), Arpauzen (Kadyrbaev , Maryashev, 2007. p. 24) and belongs to almost all rock monuments found in the mountains of Central Asia. On the east side of the river, stone paintings are more common, while on the west side of the river, stone paintings are rare. However, archeological monuments found here, including stone paintings, show that the river and its surroundings were once very rich in flora and fauna, which our ancestors used effectively. Our research on the technique of image processing has shown that the majority of the marks on the stone surface are dotted and ovoid prints. This is because the tip of any 
sharpened tool is slightly blunt when struck once or twice, resulting in a semicircular crosssection on the surface of the stone (Girya, Devlet, 2012. p. 173). The shape, depth and size of the marks left on the stone surface during painting depend in many ways on the tool used to process the pictures, its sharpness, shape, how hard it hits the stone surface and finally the softness and hardness of the stone being painted.

The surface of some ancient and later paintings consists of rough, shallow, large-shaped traces. Such paintings may also have been
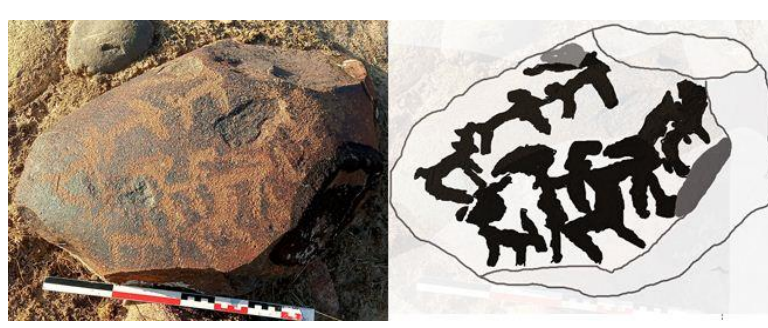

ZTP1 made of stone or worked with the help of a piece of stone. As a result of our research, we can see the similarities between Gadoytopmassoy (Oynazarov, 2019. p. 102), stone paintings and Tepaqiyassoy stone paintings. Among the rock paintings of Tepakiyasay, the images of mountain goats attract attention. The reason is that in these pictures the positions of the organs of the animal's body are vividly, naturally, skillfully depicted (Figs. ZTP1, ZTP2, ZTP4, ZTP14).
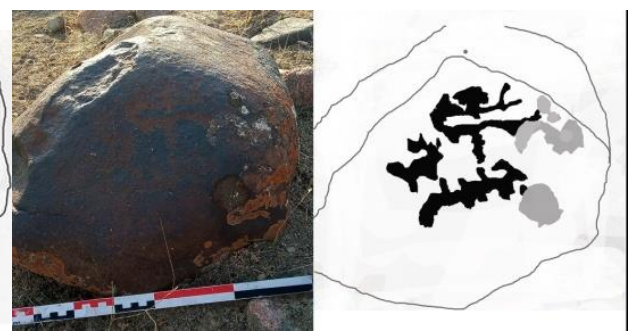

ZTP2
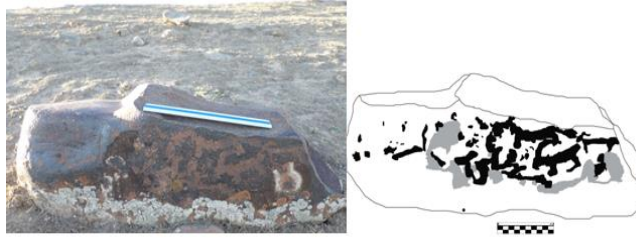

ZTP14

1- pictures -ZTP1,ZTP2,ZTP4,ZTP14

It should be noted that on the stones you can see a lot of images of various animals. Most of them are native to Central Asia, mainly Uzbekistan. The mountain goat is also common in the mountainous regions of Central Asia and beyond. The image of this animal is very common in the rocks of Central Asia. We can see similarities in the rock paintings of Tepaqiyasay, in the rock paintings of Iran (Jamal Lahafian 2013. 335) and in Azerbaijan (Mohammad Mirzaei, Najmeh Nouri, Ali Karimi, Kiya Nasrin, 2016.56p.). They are sometimes represented as solitary, and in many cases as bifurcated, long-necked, slender-bodied,

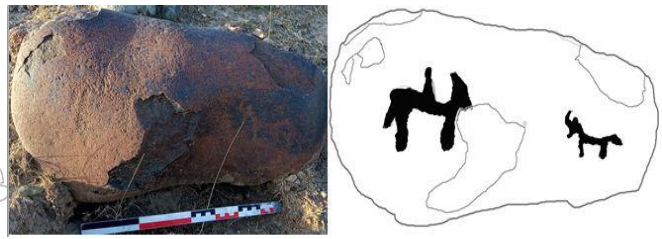

ZTP4 bipedal, and short-tailed. Among the paintings of Tepaqiyasay mil. avv. Most of the paintings were made during the first millennium. We can see the similarities when comparing the Sarmishsay and Tepaqiyasay stone paintings. Schematic and contour paintings are more common in Tepaqiyasay stone paintings. Some archeological materials are also important in determining the chronological date of the paintings found on the hill. As a result of archeological excavations carried out by the Uzbek-Czech-French international archeological expedition near the village of Zarabog, Burguttepa and Kayrit monuments were found. These monuments belong to the Late Bronze and Iron Ages. 
A ceramic seal was found near the village of Zarabog. The seal depicts a mountain goat, and among the stone paintings, mountain goat paintings are more common.

\section{CONCLUSION}

In conclusion, the scientific significance of Tepakiyasay stone paintings is that it provides a scientific basis for the emergence and development of the first works of art in the territory of Uzbekistan. It serves as a scientific source on the mythological and religious worldviews and imaginations of the ancient population. The period of Tepaqiyasay stone paintings is characterized by the Late Bronze and Early Iron Ages. Currently, our scientific work on Tepaqiyasay stone paintings is underway.

\section{REFERENCES}

1. Girya E.Yu., State E.G. Ob issledovanii tekhnik vypolneniya izobrazheniy // Problemy istorii, filologii, kultury, №1 (35). Magnitogorsk, 2012.

2. Kabirov A. Pictures on the rocks of Sarmishsay. Tashkent, 1976.

3. Kadyrbaev K.M., Maryashev A.N. Petroglyphs of Karatau. Almaty, 2007.

4. Kondrikova M., Khojanazarov $M$. Наскальные изображения Yanbashsaya // Uzbekistan in ancient times and in the Middle Ages. Samarkand, 1992.

5. Oynazarov X.G. Gadoytopmassoy petroglyphs // "Look at the past" magazine. No. 15, 2019. 98-105 bb.

6. 6.Formozov A.A. Book about ancient naskalnoy zivopisi in Uzbekistan. 1951, №3. S.213-216.

7. Formozov A.A. Essays on primitive art Naskalnbe izobrazheniya i kamennye izvayaniya epoxi kamnya i bronzy na territorii-. M., 1969.C 69-71
8. Xolmatov A. On the technical and typological study of rock paintings of the Nurata ridge (on the example of new rock paintings) // Archeology of Uzbekistan, №1 (12). Samarkand, 2016.

9. Kholmatov A.N. Nokisay new rock paintings I/ Archeology of Uzbekistan, №1. Samarkand, 2010. pp. 166-169.

10. Kholmatov AN, Khojanazarov MM Kudukchasoy rock paintings // Archeology of Uzbekistan, № 2 (9). Samarkand, 2014.

11. Xujanazarov M. Sarmishsay rock paintings research Tashkent, 2018.

12. Xujanazarov M.M. Naskalnye isobrajeniya Xodjakenta i Karakiyasaya. Samarkand, 1995.

13. Shatskiy G.B. Risunki na kamne. Tashkent, 1973.

14. Eshqurbonov S.B. Some comments on the analysis of rock art monuments // Conference of Orientalists (TDShI) №9. Tashkent, 2014. pp. 99-103.

15. Augustinová A., Stančo L. The Petroglyphs of Pashkhurt Valley in the Surkhan Darya Province (South Uzbekistan) - Preliminary Report 2016 // Studia Hercynia, XX / 2, 122138.

16. Bobomulla Bobomullaev -Soy Sabak Unikalnoe collection of petroglyphs in the top of Zaravshan // Association of the National Museum of the Republic of Tajikistan named after Kamoliddina Bekhzoda №9. 2011. 145-146

17. Jamal Lahafian Rock Art in Kurdistan Iran 2013 www.mdpi.com/journal/arts

18. Mohammad Mirzaei, Najmeh Nouri, Ali Karimi, Kiya Nasrin Analysis on Rock Art in Qarasu River Basin at MeshginShahr (Azerbaijan) Alizadeh International Journal of Archeology 2016; 4 (5) 54-60. 